\title{
Turning trash into an asset: a case study of prince sultan university campus waste
}

\author{
Shabir Hussain Khahro ${ }^{1, *}$, Tauha Hussain $\mathrm{Ali}^{2}$, Zubair Ahmed Memon ${ }^{3}$, Amjad Ali Panhwar ${ }^{4}$, Anas Haribat ${ }^{5}$ \\ Lecturer ${ }^{1}$, Department of Engineering Management, Prince Sultan University, Riyadh, Saudi Arabia \\ Professor ${ }^{2}$, Civil Engineering Department, Mehran University of Engineering \& Technology, Jamshoro, Pakistan \\ Professor ${ }^{3}$, Department of Engineering Management, Prince Sultan University, Riyadh, Saudi Arabia \\ Mechanical Engineer ${ }^{4}$, First Gulf Company, Saudi Arabia \\ Undergraduate Student ${ }^{5}$, Department of Engineering Management, Prince Sultan University, Riyadh, Saudi Arabia
}

\begin{abstract}
Concrete is one of the key material used in the construction industry. Concrete is used as a compressive material and it is also reinforced by rebar's to improve its tensile strength. Due to rapid urbanization concrete use is getting huge demand and it became a major business industry. Whereas, it also utilizes natural resources to the same hasty level. Therefore, this paper utilizes waste tissues of a university as an aggregate replacer. The different test was performed in a green and hardened state. It is observed that the new concrete is good in workability and it has normal temperature but it is not good at resisting higher compressive loads. Similarly, the waste material collected after the tests and utilized in making a commercial product. This paper aims to save the environment by utilizing different types of waste in making useful items to save resources.
\end{abstract}

\section{Introduction}

Concrete became one of the most important components in the construction industry because of its durability, strength and flexibility. Concrete can be defined as a mixed consist of coarse \& fine aggregates, water, chemical admixtures, and a binding material which is most of the time cement. Those ingredients are mixed in specific proportions in order to achieve desired properties. Chemical admixtures play an important part in obtaining desired concrete characteristics, for example, admixtures can be added to concrete to enhance its workability, waterproofing, strength, reduces setting time and segregation. Concrete is one of the major element of modern construction and it has great application in the industry starting from small homes up to skyscrapers. This special material became one of the most used materials in the $21^{\text {st }}$ century and hence, it is rapidly consuming natural resources. This research focuses on saving natural resources by utilizing waste. It enhances concrete by making it more environmentfriendly material using recyclable materials. For this study, a number of experiments have been made to test various properties of concrete. In this research, aggregates are replaced by waste tissue papers, which were collected from different offices and toilets of Prince Sultan University, Riyadh, Saudi Arabia. This research also focuses on the commercialization of such tissuecrete (Concrete made up of tissues) in making commercial items. The concrete made for experiments for this research has been utilized in making such items. Meaning that there is no waste made in this research project. Since the beginning, waste has been used and it was assured that no further waste would be generated from this activity.

This research is the first step towards the concept of turning waste in making commercialized items. It will not only utilize waste but it will help in saving natural resources, which are now used in bulk for concrete manufacturing.

\section{Literature review}

Numerous researchers carried research on concrete but their focus was to enhance the properties of concrete. The concept of using different waste items in concrete got importance in the early $20^{\text {th }}$ century. Many researchers have done the research and few are;

The accumulation of waste plastic worldwide creates serious environmental concerns [1]. Parvin examined in 2003 the effects of discrete reinforcement systems of virgin and recycled origin on the mechanical, physical and durability characteristics of concrete [2]. In 2004, Rafat worked on a 1: 1.4: 2.19 ratio control mix with a WC ratio of 0.47 . The cement was replaced with three percentages (35\%, $45 \%$ and $55 \%)$ of Class $\mathrm{F}$ flying ashes. The results of the test indicated that the substitution of cement with fly ash increased the workability (fall and time of Vebe), decreased resistance to compression, splitting tensile [3]. Sammy in 1998 describes the use of bituminous shale as a partial replacement material for cement. The results of the test show that for substitution levels between 5 and $20 \%$, the shale bituminous ash, although not as effective as silica

* Corresponding author: shkhahro@psu.edu.sa 
smoke, could increase resistance, reduce water absorption capacity and chloride of cement [4].

Jorge in 2012 used corn cob as lightweight aggregate. The density, compressive strength and thermal insulation properties of a corn cob concrete have been experimentally quantified [5]. In 2007, Bekir stated that the use of fly ash in concrete can offer economic advantages and better properties in concrete production [6]. The use of various waste materials and by-products such as coal combustion products (fly ash, heavy ash), spent foundry sand, cement kiln dust, wood ashes and rubber tires have been used by various researchers [7]. In 2006, Deepa stated that rice husk with a binding agent can give better results in rural areas with low strength required [8]. The results of the 2008 Van research presented the use of recycled composite would prove to be an efficient and economical supplement for standard fibreglass insulation in light-frame residential structures [9].

In 2010, Wong used bamboo fibres in his research and resulted that it deteriorates the fracture toughness [10]. Fly ash content used in concrete mixture and the results showed the inclusion of fly ash improves reported by Okan in 2011 [11]. In 2011, Younsi concluded that reduction of cement content is assumed to mitigate $\mathrm{CO}_{2}$ emissions due to the production of Portland cement clinker [12]. Elfordy in 2008 prepared concrete blocks using lime and hemp [13].

Bashar studied the use of paper mill waste in concrete formulations in 2011 as an alternative to landfill disposal [14]. Self-compacting concrete with waste materials offers a sustainable alternative to minimize environmental damage associated with the extraction and depletion of natural resources [15]. In recent years, a growing number of researches has been conducted on recycling brick waste to produce greener concrete [16]. In the present study, we see that the residual marble is widely used in concrete rather than in aggregate and in cement [17].

It has been observed from this detailed literature review that replacement of aggregate with paper tissues is rarely discussed. The tissue has been used as a cement replacement material but not as an aggregate replacement. Hence, this research focused on the use of paper tissues waste of Prince Sultan University in concrete as an aggregate replacement.

\section{Problem statement}

Concrete has been rapidly consuming natural resources as it is one of the major materials required for all types of infrastructures. Thus, it is very important to take the necessary measures from now to save natural recourses. It has been observed that Plastic Bottles, Paper and Tissue Papers are major wastes of an academic infrastructure like University. These waste items can be harmful to the environment so it would be better to make such advance methods and ways to convert these waste items into a useful entity.

\section{Research objectives}

The aim of the study is to convert trash (waste) into an asset. This research focuses on using waste and saving environment, especially in the Middle East. To reach this aim following objectives were designed;

1. Use waste tissues in concrete.

2. Analyze the green properties of new concrete.

3. Analyze the crushing strength of new concrete.

4. Utilize new concrete into a commercial item.

\section{Research methodology}

The complete research has been done using the following flowchart shown in Figure 1.

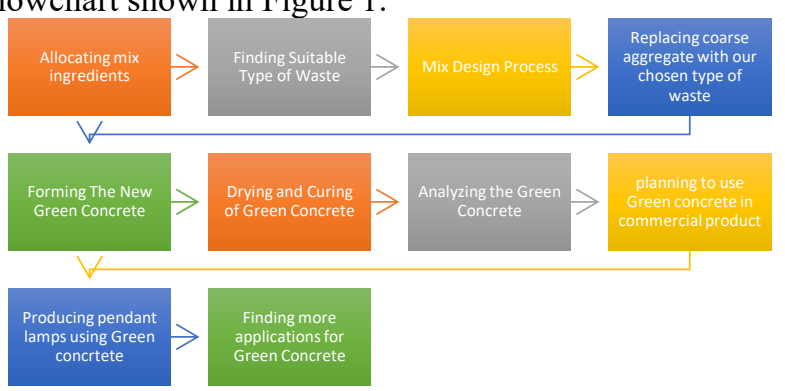

Fig. 1. Research Flowchart of the Study

In the first stage, a mix design has been designed to prepare concrete. In the next phase, the tissue waste has been collected from different points of Prince Sultan University and processed as per the requirement of the design. Later on, batching has been done followed by mixing, placing, compacting, finishing and curing of concrete. Different tests were made after the concrete is prepared and in the next phase, concrete was casted in different cylinders for testing purpose and moulds for commercialization purpose. Following tests were performed to analyze the properties of concrete; Concrete Workability Test, Concrete Temperature Analysis, Concrete Crushing Strength

\section{Experiments and results}

As mentioned earlier, waste was collected from different locations of PSU and materials were weighted as per mix design requirements as shown in Figure 2.

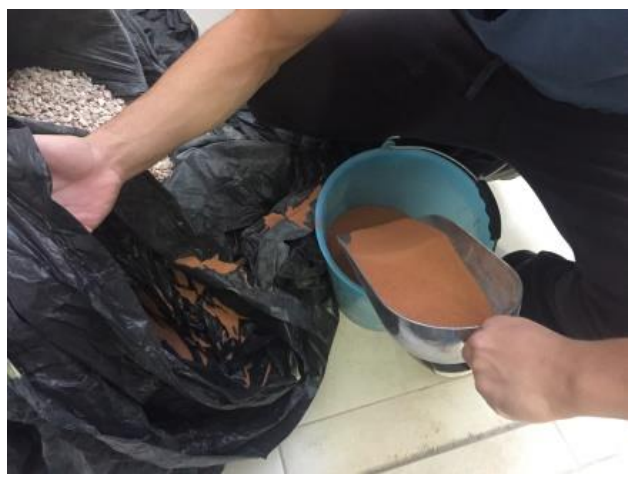

Fig. 2. Batching

In the next phase, waste tissues were crushed with the help of grinder as shown in Figure 3. 


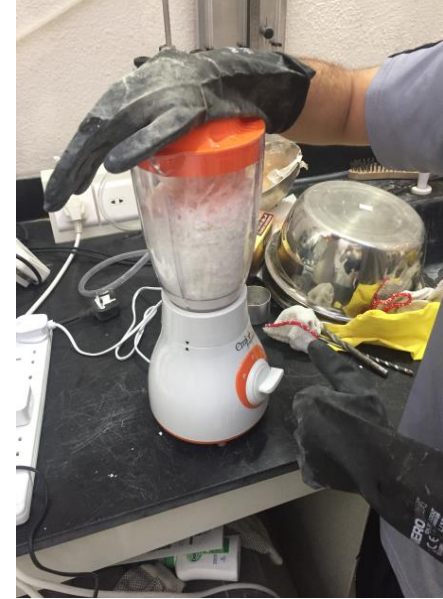

Fig. 3. Processing Waste Tissue

In the next phase, all the ingredients were mixed properly and water has been added as per the requirement of mix design as shown in Figure 4.

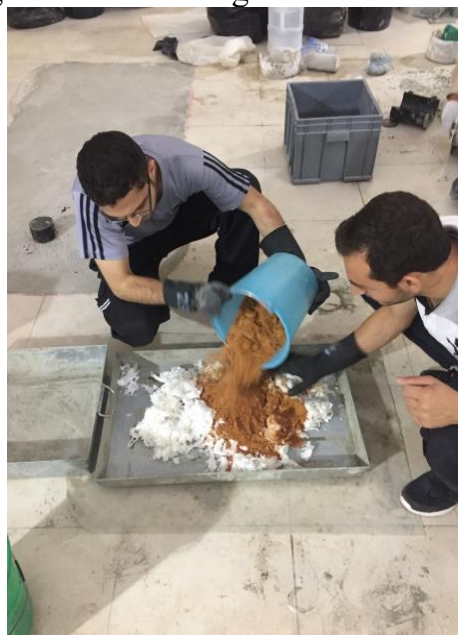

Fig. 4. Mixing of Concrete Ingredients

In the next phase, the concrete temperature was tested which was 28 degree Celsius recorded in the room temperature. Slump cone method has been used for analyzing workability of concrete. It is the most common method widely used in the experimental labs and field due to its easiness and results. 1.5-inch fall was recorded during the slump test. Later on, 6 cylinders of 6-inch height were casted for testing purpose and a marginal addition of water has been made to enhance the workability of concrete. The reason for this task is the gape in the moulds, which were made from plastic waste water bottles collected from PSU campus. As it was planned to make LAMPS as a commercial item so if there will be higher gape then in result the weight of the lamp will be high so it avoids this problem it was decided to make low gape between the moulds for the lamp.

Finally, the cylinders were tested to analyze the crushing strength after 3 and 7 days curing which was achieved as 1600 Psi as shown in figure 5.

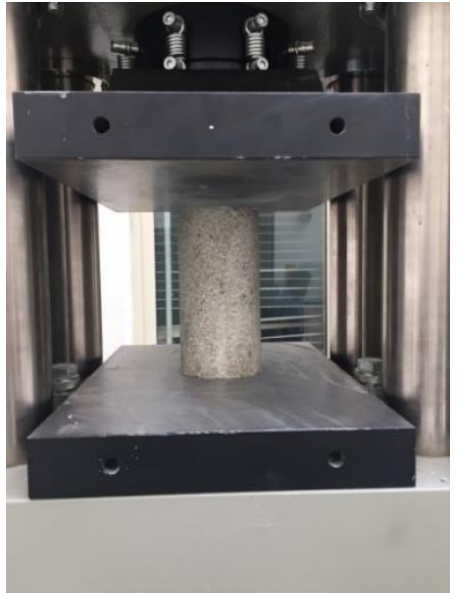

Fig. 5. Crushing Test

The further arrangements for the commercial items were made and testing has been carried out to see the working performance of the lamp as shown in Figure 6.

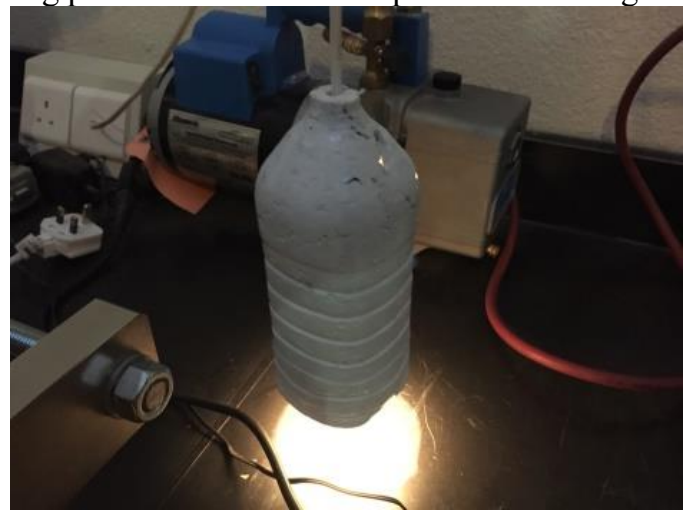

Fig. 6. Test Commercial Item

Finally, after testing the lamps the final phase was to colour the lamps. So, colour sprays were used for this task and the final product is shown in Figure 7.

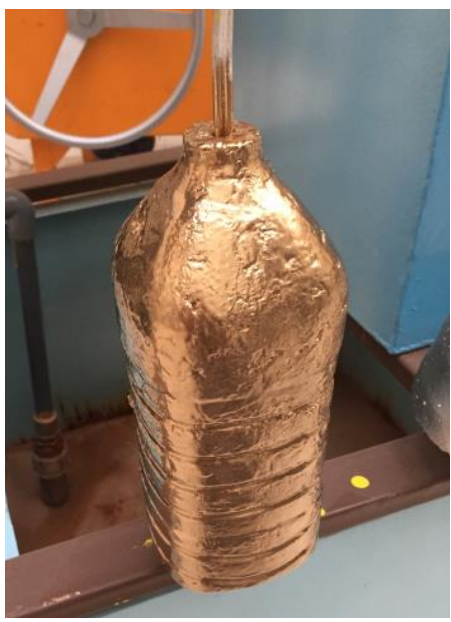

Fig. 7. Final Commercial Item (Lamp)

The complete test results are shown in Table 1. 
Table 1. Concrete Assessment Sheet

\begin{tabular}{|c|c|c|}
\hline S.No & Test Name & Result \\
\hline 1 & Slump Test & 1.5 inch \\
\hline 2 & Temperature & 28 Deg C \\
\hline 3 & Shrinkage (Green State) & Non \\
\hline 4 & Odour (Green State) & Normal \\
\hline 5 & Shrinkage (Harden State) & 1 cm \\
\hline 6 & Odour (Harden State) & $\begin{array}{c}\text { Normal } \\
\text { (Acceptable) }\end{array}$ \\
\hline 7 & $\begin{array}{r}\text { Compressive Strength }(7 \\
\text { days) }\end{array}$ & Avg: 1600 psi \\
\hline
\end{tabular}

\section{Conclusion}

A reasonable strength has been achieved by this tissuecrete but it can be used for all items of the construction industry where low strength is required rather than high strength. It is a step forward in having a green environment where waste can be used in a beneficial product rather than being thrown away. This research can be used in order to reduce the cost of concrete and saving natural aggregates. It can be applied to many aspects of the construction industry where high strength is not needed like pedestrian paths, blocks for pathways etc.

This attempt is the first of its type in KSA where university waste has been used to make a valuable commercial item. Such concrete can be used in manufacturing other commercial products. The most important point of this research is that paper tissues waste can be used to produce usable products, so it is a sort of improved recycling of tissue papers.

\section{Future research}

This research can be carried out in various scenarios depending on resources, availability of funds, tools, equipments and expertise. A detailed experiment analysis can be done with tissuecrete and further tests can also be made to assure the quality of the product.

The authors are thankful to Prince Sultan University, Riyadh for providing a platform to conduct this research.

\section{References}

1. A. Jain, S. Siddique, T. Gupta, S. Jain, R. K. Sharma, and S. Chaudhary, "Fresh, Strength, Durability and Microstructural Properties of Shredded Waste Plastic Concrete," Iran. J. Sci. Technol. - Trans. Civ. Eng., vol. 43, pp. 455-465, 2019.

2. P. Soroushian, J. Plasencia, and S. Ravanbakhsh, "Assessment of reinforcing effects of recycled plastic and paper in concrete," ACI Mater. J., vol. 100, no. 3, pp. 203-207, 2003.
3. R. Siddique, "Properties of concrete incorporating high volumes of class F fly ash and san fibers," Cem. Concr. Res., vol. 34, no. 1, pp. 37-42, 2004.

4. S. Y. N. Chan and X. Ji, "Water sorptivity and chloride diffusivity of oil shale ash concrete," Constr. Build. Mater., vol. 12, no. 4, pp. 177-183, 1998.

5. J. Pinto et al., "Corn cob lightweight concrete for nonstructural applications," Constr. Build. Mater., vol. 34, pp. 346-351, 2012.

6. I. B. Topçu and M. Canbaz, "Effect of different fibers on the mechanical properties of concrete containing fly ash," Constr. Build. Mater., vol. 21, no. 7, pp. 1486-1491, 2007.

7. R. Siddique, "Utilization of waste materials and byproducts in producing controlled low-strength materials," Resour. Conserv. Recycle., vol. 54, no. 1, pp. 1-8, 2009.

8. D. G. Nair, K. S. Jagadish, and A. Fraaij, "Reactive pozzolanas from rice husk ash: An alternative to cement for rural housing," Cem. Concr. Res., vol. 36, no. 6, pp. 1062-1071, 2006.

9. J. W. van de Lindt, J. A. H. Carraro, P. R. Heyliger, and C. Choi, "Application and feasibility of coal fly ash and scrap tire fiber as wood wall insulation supplements in residential buildings," Resour. Conserv. Recycle., vol. 52, no. 10, pp. 1235-1240, 2008.

10. K. J. Wong, S. Zahi, K. O. Low, and C. C. Lim, "Fracture characterisation of short bamboo fibre reinforced polyester composites," Mater. Des., vol. 31, no. 9, pp. 4147-4154, 2010.

11. O. Karahan and C. D. Atiş, "The durability properties of polypropylene fiber reinforced fly ash concrete," Mater. Des., vol. 32, no. 2, pp. 1044-1049, 2011.

12. A. Younsi, P. Turcry, E. Rozire, A. Ait-Mokhtar, and A. Loukili, "Performance-based design and carbonation of concrete with high fly ash content," Cem. Concr. Compos., vol. 33, no. 10, pp. 993-1000, 2011.

13. S. Elfordy, F. Lucas, F. Tancret, Y. Scudeller, and L. Goudet, "Mechanical and thermal properties of lime and hemp concrete ('hempcrete') manufactured by a projection process," Constr. Build. Mater., vol. 22, no. 10, pp. 2116-2123, 2008.

14. B. S. Mohammed and O. C. Fang, "Mechanical and durability properties of concretes containing papermill residuals and fly ash," Constr. Build. Mater., vol. 25, no. 2, pp. 717-725, 2011.

15. F. Aslani, G. Ma, D. L. Yim Wan, and G. Muselin, "Development of high-performance self-compacting concrete using waste recycled concrete aggregates and rubber granules," J. Clean. Prod., vol. 182, pp. 553$566,2018$.

16. C. L. Wong, K. H. Mo, S. P. Yap, U. J. Alengaram, and T. C. Ling, "Potential use of brick waste as alternate concrete-making materials: A review," $J$. Clean. Prod., vol. 195, pp. 226-239, 2018. 
17. E. Tugrul Tunc, "Recycling of marble waste: A review based on strength of concrete containing marble waste," J. Environ. Manage., vol. 231, pp. 8697, 2019. 